\title{
Development Strategy of Brau Edufarm Tourism in Batu
}

\author{
Siti Zurinani ${ }^{1 *}$, Nurul Rodiyah ${ }^{1}$, Dikau Tondo Prastyo ${ }^{2}$, Muhammad Yogi Arifky Zuhri $^{3}$ \\ ${ }^{1}$ Departement of Anthropology, Faculty of Cultural Studies, University of Brawijaya, Malang, Indonesia \\ ${ }^{2}$ Department of Economic and Development Studies, Faculty of Economics and Business, University of Brawijaya, \\ Malang, Indonesia \\ ${ }^{4}$ Department of English Literature, Faculty of Cultural Studies, University of Brawijaya, Malang, Indonesia
}

\begin{abstract}
Brau Hamlet is a hamlet located in Batu City included in the category of underdeveloped Inpres regional where people's livelihoods are only based on dairy farming. Brau hamlet is known as the village of 1000 cows; the second largest after the Hamlet of Toyomerto in the city of Batu. Brau Hamlet is a hilly area with beautiful natural scenery. Brau hamlet has tourism and agricultural potential, but so far it has not been identified and mapped in an integrated manner. This study aims to formulate a strategy for developing edu farm tourism in Brau hamlet. Tourist Attractions in Brau Hamlet having the potential to be developed are edu farm tourism. The strategy of developing edu farm tourism in Brau Hamlet is in quadrant 1 which means that the strategy is done aggressively using the concentration of vertical integration. Vertical integration is carried out at all stages of the supply chain of cattle farms from upstream to downstream, such as; (1) Dairy Cow Nursery; (2) Provision of Feed; (3) Health access to Dairy Cows; (4) Processing cow's milk into finished products; (5) Waste treatment; (6) Product Marketing. As for the SWOT matrix, the biggest total score of the combination of internal factors and external factors is to strengthen the brand back to nature and always give innovation to tourist rides (S1.5 and T1.4) of 1.65. Based on the Internal External (IE) matrix analysis, the total value of IFAS and EFAS parameters is in cell 4. The strategy taken is growth strategy by carrying out vertical integration and slowly and carefully developing tourism management.
\end{abstract}

Keywords: CBT, Edufarm, Development, tourist attraction object, Strategy

\section{INTRODUCTION}

The Government of Batu City becomes one of the local governments in Indonesia concentrating on developing the tourism sector into its economic base. It reflected in the branding of Kota Wisata Batu (Batu Tourism City) icon. Tourism development in Batu City driven by many potentials of the tourism sector, such as agriculture, forestry, and artificial tourism. The tourism potential owned by Batu City is not only the charming nature, but also the typical customs, innovative landscape heritage, and the potential of education in husbandry [1,2].

Batu City consists of three districts i.e. Batu City, Bumiaji, and Junrejo. Each of them has the potential for developing tourism. One of them is Bumiaji Sub-district which specifically has the potential of agriculture, plantation, animal husbandry, and forestry. In this district, there is an underdeveloped Inpres region, namely Brau hamlet, Gunungsari Village. Brau is administratively adjacent to Pandesari Pujon Village (Malang Regency), south is adjacent to

\footnotetext{
* Correspondence address:

Siti Zurinani

Email : zurienani@gmail.com

Address : Dept. Anthropology, Faculty of Cultural Studies, University of Brawijaya, Veteran Malang, 65145.
}

Paralayang in Gunung Banyak area, and north is Jantur Hamlet, Celaket Hamlet in the east.

Access to Brau by the tendency of hilly areas has the potential to be used as trekking tours. Meanwhile, most people in Brau work as dairy farmers, of which the population of the Brau Hamlet with a greater number of cattle is a cow population. In each family, at least they have 5 dairy cows. Brau hamlet is known for its brand of the village of 1000 cows, which number is ranked $2^{\text {nd }}$ in Batu City after Toyomerto Hamlet.

Through the potential of existing dairy farms, the residents of Brau Hamlet wish that livestock tourism can be developed in the hamlet. The expectations of Brau residents are the attending visitors are not just a mere picnic and then return home. But residents hope that visitors will get something by visiting the hamlet (experience). However, livestock tourism villages are still limited to be realized because there is no competency of people to formulate a strategy in developing livestock tourism villages that is appropriate and economical for Brau Hamlet. Therefore, the outcome of this study will be recommended as a strategy to develop livestock education and processed livestock tourism (farm edu tourism) to the Tourism Office and Government of Batu City as a pioneering model of underdeveloped village development in increasing regional economic independence as 
one of the pillars in realizing village universe and sharing economy.

Tourism can be a strategy to improve community welfare [3]. Community involvement from the planning level is the most vital aspect especially people playing an active role as the subject of development. The target of tourism object development planning will reach to build prosperous village communities around tourist sites [4].

To answer these challenges, Brau Hamlet need to develop an educational tourism paradigm focusing more on active participation from the community. In tourism, current tourist demand is not merely seeking satisfaction or enjoy, but the orientation into learning, experience, and challenges that possibly packaged by local residents [5]. Educationalbased tourism is one of the lighters so that tourists will visit to realize sustainable development.

Considering on tourism that has developed in Brau Hamlet is still limited although the biodiversity of tourist attraction objects is very supportive. So far, the economic activities of the Brau Hamlet community have only based on primary livestock products. For the example, livestock and fresh milk are sold to cooperatives so that people's income tends on being stagnant due to the absence of value added from livestock activities that are carried out (not oriented to the development of current market demand). This makes Brau Hamlet community become relatively disadvantaged compared to other Batu area communities that economic growth is more advanced due to the development of a special interest tourism sector.

Finally, the remaining stigma when people hear Brau Hamlet is the area in the marginalized (isolated) Batu City so that it is necessary to create value-added livestock activities and tourism potential in Brau Hamlet to improve the economy of local communities. Therefore, the purpose of this paper is to map the potential of tourist attraction, as well as formulate a strategy for developing community-based edu farm tourism.

\section{MATERIAL AND METHOD \\ Study sites}

Brau Hamlet is close to popular tourism such as Paragliding, Rabbit Park, and Omah Kayu (tree house). However, the residents of Brau Hamlet do not have access for selling or being involved in the development of such popular tourism, which eventually leads to inequality in welfare and social jealousy towards the residents of Brau Hamlet.

Geographically, the area around the Brau Hamlet is a potential area to be developed into a tourist attraction. The morphology of the land in Brau Hamlet is a type of hilly, fields, and surrounded by pine forests. The land used as a residential area is also used as a field to grow vegetables such as corn and for growing cattle feed. If it is mapped, the Brau hamlet has several tourism potentials to be developed, namely dairy farming, Goa Pandawa natural tourism, pine forest, and cow's milk processing industry. But so far there has not been an optimal mapping and development of the tourism potential.

\section{Data Collection and Data Analysis}

The method applied in this research includes an interview, analytical hierarchy process, survey, and questionnaire. Data collection techniques were obtained from (1) literature to obtain a global description of the evaluation of Tourist Attraction Objects (ODTW); (2) field observations, to observe the culture, socioeconomic aspects of the community, and biophysics accompanied by the taking of coordinate points by utilizing GPS technology in every object and tourist attraction; (3) interviews and questionnaires, to retrieve primary data in a holistic and ethnographic field in making strategies to develop community-based tourism (CBT).

Interviews were carried out by involving village officials, tourism agencies, and tourism managers to discuss the potential of Attraction and Tourism Attractions. It is also about strategies in developing economy and efficient educational farm programs. The dissemination of the questionnaire aimed to determine the extent of people's insight into farm edu tourism, and how the readiness and willingness of the Brau Hamlet community to participate in realizing the farm edu tourism program; (4) Analysis of the hierarchical process was conducted to produce weight among factors used in farm edu tourism development strategy. Then, it was analyzed with IFAS and EFAS, scoring with key respondents and the results place on the IE matrix and space matrix; (5) SWOT analysis was to develop strategies by considering strengths, weaknesses, opportunities, and threats that become strategies for developing edu tourism farms (Fig.1). 


\section{RESULTS}

Farm Edu Tourism Development in Brau Hamlet

Potential Tourist Attraction Objects (ODTW)

in Brau Hamlet described in Table 1. The development strategy of Brau Hamlet farm edu tourism is obtained through several stages of analysis which include AHP, SWOT (IFAS Method, EFAS Method), IE Matrix Method, and Space Matrix Method. The steps in the analysis of the strategy are as follows:

\section{Hierarchy Process}

The hierarchy of strategies for the development of the Brau Hamlet farm edu tourism is presented in Figure 2.

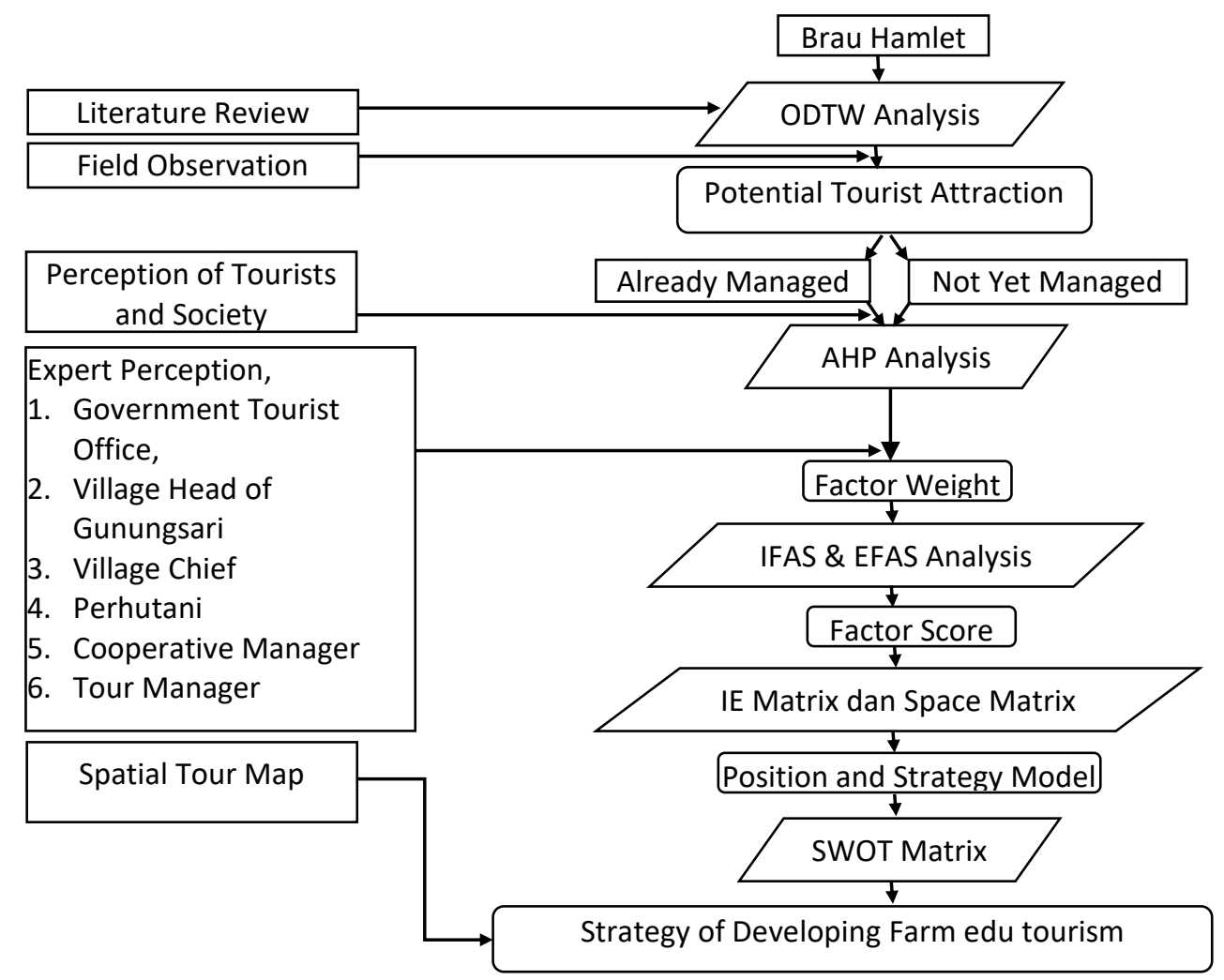

Figure 1. Flowchart of Data Analysis Method

Table 1. Tourist Attraction Objects of Brau Hamlet, Gunungsari Village

\begin{tabular}{|c|c|c|c|c|c|c|c|}
\hline \multirow{2}{*}{ Object Name } & \multicolumn{2}{|c|}{ Coordinate } & \multicolumn{3}{|c|}{ Contex } & \multicolumn{2}{|c|}{ Potential Tourist } \\
\hline & $\mathrm{X}$ & $\mathbf{Y}$ & Landscape & Landform & Ownership & Type & Specific \\
\hline Milk Stick & 0664550 & 9131618 & Settlement & Plain & Personal & Domestic Industry & Culinary \\
\hline $\begin{array}{l}\text { Paralayang } \\
\text { Tours }\end{array}$ & 0665291 & 9131317 & - & Hilltop & PERHUTANI & Special Interest & Paralayang \\
\hline Gua Pinus & 664302 & 913719 & Forest & Slope & PERHUTANI & Special Interest & Trekking \\
\hline $\begin{array}{l}\text { Livestock and } \\
\text { Biogas }\end{array}$ & 664925 & 9131465 & Settlement & Plain & Personal & Domestic Industry & Education \\
\hline $\begin{array}{l}\text { Kampung } \\
\text { Papua }\end{array}$ & - & - & Forest & Slope & $\begin{array}{l}\text { Cooperation among } \\
\text { PERHUTANI, Margo } \\
\text { Makmur cooperation, } \\
\text { and } 4 \text { Brau's People }\end{array}$ & Special Interest & Selfie Tourism \\
\hline $\begin{array}{l}\text { Goa Pandawa } \\
\text { Park }\end{array}$ & - & - & Forest & Hilltop & $\begin{array}{l}\text { Self-help People of } \\
\text { Brau Atas Hamlet }\end{array}$ & Special Interest & Selfie Tourism \\
\hline
\end{tabular}




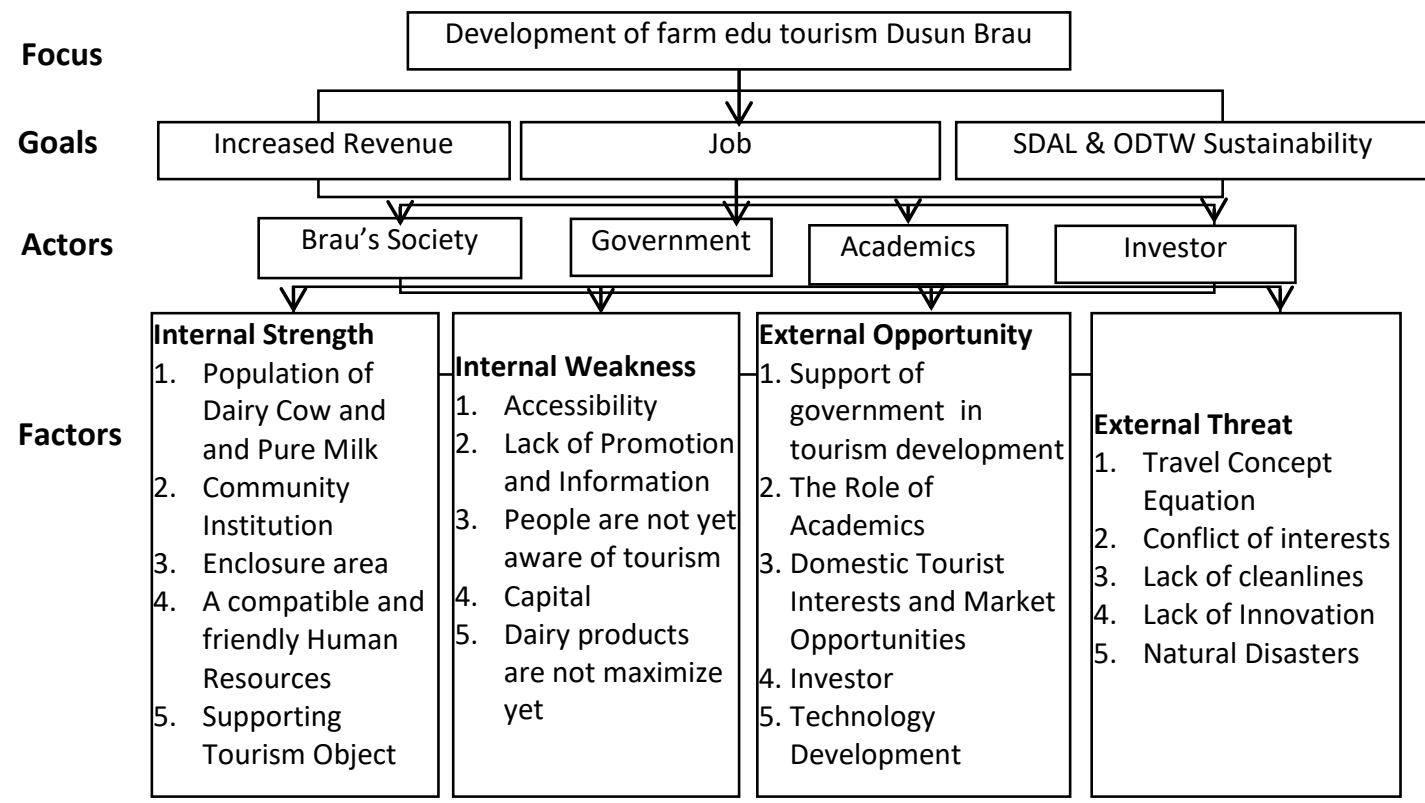

Figure 2. Hierarchical Structure of Strategy of Farm Edu Tourism

Based on Figure 2 above, it is explained that coordination between stakeholders (development actors) has a vital role in realizing edu tourism farms. Thus, the assessment of expert respondents was analyzed by using AHP (Analytical Hierarchy Process) producing quantitative values of each factor. This value will be the weight for the next analysis, namely IFAS and EFAS analysis.

\section{Internal and External Strategy Factor Analysis}

After obtaining factor weights in the AHP analysis, the next is the preparation of the Internal Strategic Factors Analysis Summary matrix (IFAS) and External Strategic Factor Analysis Summary (EFAS) as control attribution [7] presented in Table 2 and 3.

Table 2. IFAS Matrix

\begin{tabular}{|c|c|c|c|}
\hline Internal Strategy Factors & Weight & Rating & Score \\
\hline \multicolumn{4}{|l|}{ Strength } \\
\hline $\begin{array}{l}\text { Population of Dairy Cow and } \\
\text { Pure Milk }\end{array}$ & 0.2 & 4 & 0.8 \\
\hline Community Institution & 0.1 & 3 & 0.3 \\
\hline Enclosure area & 0.05 & 3 & 0.15 \\
\hline $\begin{array}{l}\text { A compatible and friendly } \\
\text { human Resources }\end{array}$ & 0.05 & 2 & 0.1 \\
\hline Supporting Tourism Object & 0.1 & 2 & 0.2 \\
\hline \multicolumn{4}{|l|}{ Weakness } \\
\hline Accessibility & 0.15 & 4 & 0.6 \\
\hline $\begin{array}{l}\text { Lack of Promotion and } \\
\text { Information }\end{array}$ & 0.1 & 3 & 0.3 \\
\hline $\begin{array}{l}\text { People are not yet aware of } \\
\text { tourism }\end{array}$ & 0.1 & 3 & 0.3 \\
\hline Capital & 0.05 & 2 & 0.1 \\
\hline $\begin{array}{l}\text { Dairy products are not } \\
\text { maximize yet }\end{array}$ & 0.1 & 2 & 0.2 \\
\hline TOTAL & & & 3.05 \\
\hline
\end{tabular}

Table 3. EFAS Matrix

\begin{tabular}{|c|c|c|c|}
\hline External Strategy Factors & Weight & Rating & Score \\
\hline \multicolumn{4}{|l|}{ Opportunity } \\
\hline $\begin{array}{l}\text { Support of government in } \\
\text { tourism development }\end{array}$ & 0.125 & 3 & 0.375 \\
\hline Support of Academics & 0.1 & 3 & 0.3 \\
\hline $\begin{array}{l}\text { Domestic Tourist Interests } \\
\text { and Market Opportunities }\end{array}$ & 0.1 & 3 & 0.3 \\
\hline Investor & 0.075 & 2 & 0.15 \\
\hline Technology Development & 0.1 & 2 & 0.2 \\
\hline \multicolumn{4}{|l|}{ Threat } \\
\hline Travel Concept Equation & 0.1 & 2 & 0.2 \\
\hline Conflict of interests & 0.15 & 3 & 0.45 \\
\hline Lack of cleanliness & 0.05 & 2 & 0.1 \\
\hline Lack of Innovation & 0.15 & 3 & 0.45 \\
\hline Natural Disasters & 0.05 & 2 & 0.1 \\
\hline TOTAL & & & 2.625 \\
\hline
\end{tabular}

Based on the results of Table 2 and Table 3, the total values of IFAS and EFAS will be used in internal-external matrix analysis (IE Matrix) and matrix space analysis.

\section{Analysis of Internal -External Matrix (IE Matrix)}

Based on the results of IFAS and EFAS analysis, the total score of internal factors is 3.05, and the total external factor value is 2.625 . Each of these parameters is mapped into the IE matrix which then reflects the development strategy of the Brau Hamlet farm edu tourism object as shown in Figure 3.

Figure 3 showed that the total value of IFAS and EFAS parameters is in cell 4 . It means that the strategy or policy taken is a growth strategy by carrying out vertical integration, slowly, and 
carefully developing existing tourism management $[8,9]$.

Vertical integration is implemented by strengthening the supply chain of cattle farms from upstream to downstream including; (1) Dairy Cow Nursery; (2) Provision of Feed; (3) Health access to Dairy Cows; (4) Processing cow's milk into finished products; (5) Waste treatment; (6) Product Marketing.

\section{Matriks Space Analysis}

Matrix space analysis is used to sharpen the strategy by using the difference from the internal score (strength and weakness) and the difference from the external score (opportunity and threat) with the following calculations:

Strength - Weakness $=1.55-1.5=0.05$

Opportunity - Threat $=1.325-1.3=0.025$
Figure 4, it shows that the strategy to develop farm edu tourism in Brau hamlet is in quadrant 1 , which means that the strategy is done aggressively. Aggressive strategies are carried out including; (1). Excellence in overall costs, namely controlling costs aggressively, effectively, efficiently and sustainably; (2) Differentiation, which is to create uniqueness in the edu tourism farm that is felt by tourists; (3) Focus, namely prioritizing tourist needs and satisfaction as a basis for development. This position is advantageous considering Batu City with the brand image of a tourist city so that the village of Brau can continue to develop its tourism potential because it has the power to capture and take advantage of the opportunities available.

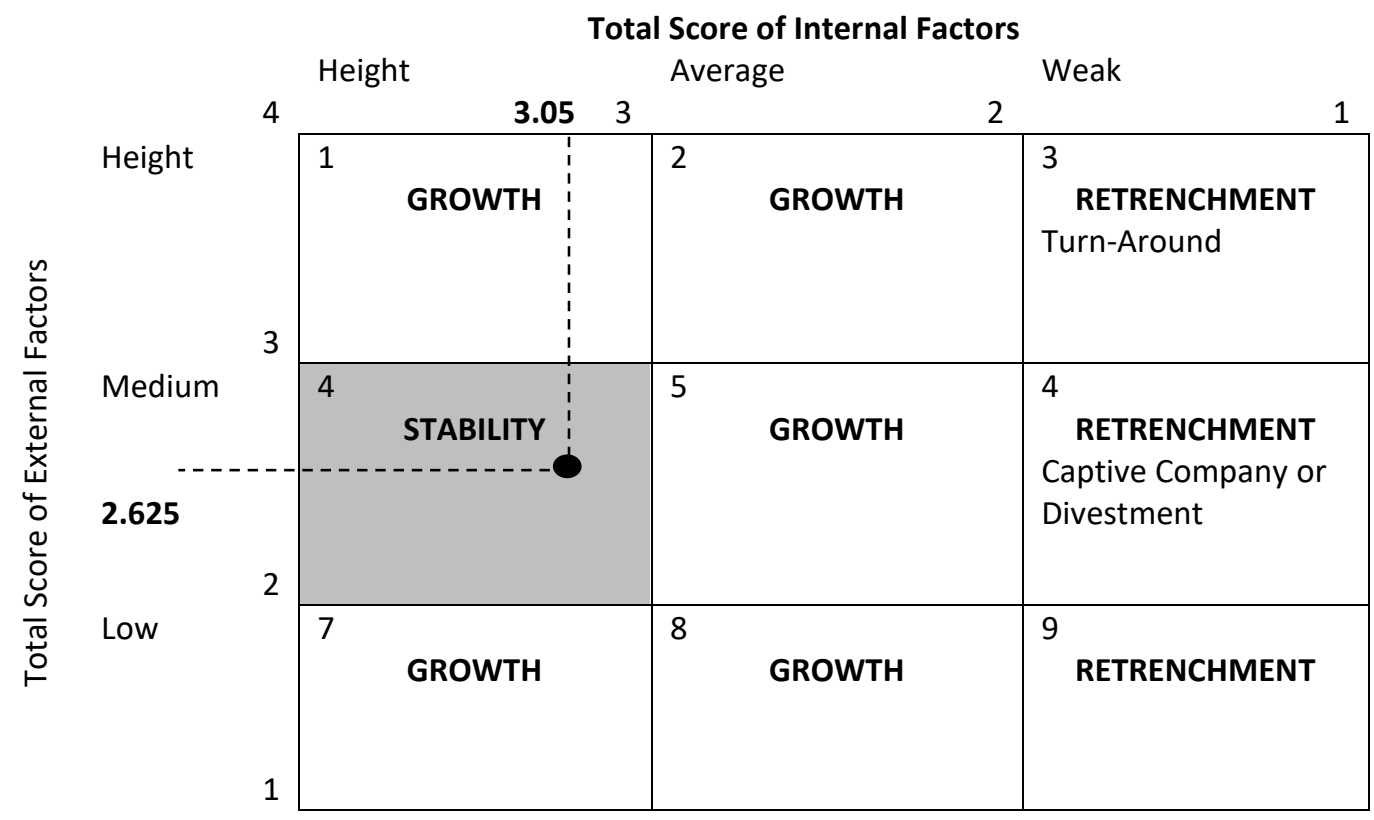

Figure 3. Internal-Eksternal Matrix based on Rangkuti [10]

\begin{tabular}{|c|c|c|c|}
\hline \multicolumn{4}{|c|}{ Opportunities } \\
\hline \multirow{2}{*}{ Internal Weakness } & $\begin{array}{c}\text { Quadran III } \\
\text { Turn Around Strategy }\end{array}$ & $\begin{array}{c}\text { Quadran 1 } \\
\text { Agresive Strategy } \\
\text { (0.05; 0.025) }\end{array}$ & \multirow{2}{*}{ Internal Strength } \\
\hline & $\begin{array}{c}\text { Defensive Strategy } \\
\text { Quadran IV }\end{array}$ & $\begin{array}{c}\text { Diversification Strategy } \\
\text { Quadran II }\end{array}$ & \\
\hline
\end{tabular}

Figure 4. Result of Space Matrix Analysis based on Rangkuti [10]. 
Geographically, the Brau hamlet is a remote area surrounded by hills with damaged road access and uneven contours. The strategy to overcome accessibility problems towards Brau hamlet is to cooperate with city transportation as a mode of shuttle transportation from tourist objects that have been crowded to get to Brau edu tourism farm (W1 \& T2.4 = 1.5). In addition, managers between attractions can manage tour packages with one pass ticket.

Road access is also a vital part to be repaired, and the government through its allocation function is expected to immediately re-pave the road to the Brau hamlet. Infrastructure facilities for the convenience of tourists need to be built through cooperation with investors both from the addition of artificial tourist objects, toilets, prayer rooms, seats, parking lots, etc. (W1.4 \& O1.4 $=1.225)(\mathrm{W} 4 \&$ T 3.5$)=0.65$

The construction of this facility must meet the RTRW, AMDAL, and tourism safety and in accordance with the management competencies (S3.4 \& T3.5 $=0.45$ ). Residents need to optimize the development of the quality of basic facilities and infrastructure at the location of tourist objects, such as cowhouse management and maintain the availability of feed so that cows as potential or attraction of edu tourism farms grow significantly. The community can increase the capacity of its human resources by making various dairy products and processing livestock waste to make organic fertilizer.

The government then needs to neutralize the promotion of edu farm tourism and build adequate accessibility and spoil tourists' desires. The actions that can be taken by the government are paving the road in Brau Hamlet, increasing capital access for biogas installations to develop Brau Hamlet as an agro-tourism area in accordance with the Batu City agropolitan masterplan.

\section{Development Model Plan}

Seeing the potential of Brau, this area has the potential to become a tourist area, especially educational tourism. Educational tourism that can be developed in the Brau area is dairy cow education. The development that has been initiated by the community towards the results of dairy cows is to make biogas. However, this business is also not evenly distributed in the Brau community, and only about $40 \%$ of the Brau people enjoy the use of this biogas. With the potential of this new community, the potential for dairy education tourism can be mapped where this tour can work with tourism that is already existed around (Table 5). The implementation of the concept of educational tourism in this area can be mapped as a tourist path and livestock infrastructure scheme in following Figure 5.

Table 5. Activity and Users of Tourist Attraction in Brau Hamlet

\begin{tabular}{|c|c|c|c|c|c|}
\hline No & $\begin{array}{l}\text { Activity } \\
\text { Group }\end{array}$ & Type of Activity & Place & Characteristics of Place & $\begin{array}{c}\text { User } \\
\text { Characteristics }\end{array}$ \\
\hline 1 & Main Function & Education Center & Livestock and Biogas & $\begin{array}{l}\text { Livestock place as educational } \\
\text { tourism }\end{array}$ & $\begin{array}{l}\text { Tourist and Cattle } \\
\text { Raiser }\end{array}$ \\
\hline \multirow[t]{3}{*}{2} & $\begin{array}{l}\text { Secondary } \\
\text { Function }\end{array}$ & $\begin{array}{l}\text { Special Interest } \\
\text { Tourist }\end{array}$ & $\begin{array}{l}\text { Goa Pinus dan } \\
\text { Kampung Papua }\end{array}$ & Place to enjoy natural view & Tourist \\
\hline & & & $\begin{array}{l}\text { Goa Pandawa } \\
\text { Dairy Products }\end{array}$ & $\begin{array}{l}\text { Place to enjoy natural view } \\
\text { Place to know and be involved } \\
\text { in the culinary process }\end{array}$ & $\begin{array}{l}\text { Tourist } \\
\text { Tourist }\end{array}$ \\
\hline & & & $\begin{array}{l}\text { Bantengan Art dan } \\
\text { Gallery }\end{array}$ & To know what Bantengan Art is & Tourist \\
\hline \multirow[t]{8}{*}{3} & Tertiary & Facilities and & Toilet & Support Facility & Tourist \\
\hline & Function & Infrastructures & Mosque & Place of Worship & $\begin{array}{l}\text { Tourist and Tour } \\
\text { Manager }\end{array}$ \\
\hline & & & Information Building & Information Center & $\begin{array}{l}\text { Tourist and Tour } \\
\text { Manager }\end{array}$ \\
\hline & & & Make Up Room & Make Up Room & $\begin{array}{l}\text { Actress, Actor, and } \\
\text { Tourist }\end{array}$ \\
\hline & & Trade and Service & Ticketing & Ticketing & Tourist \\
\hline & & & Foodcourth & Support Facility & Tourist \\
\hline & & & Lounge Place & Support Facility & Tourist \\
\hline & & Parking & Parking Area & Parking Area & Tourist \\
\hline
\end{tabular}



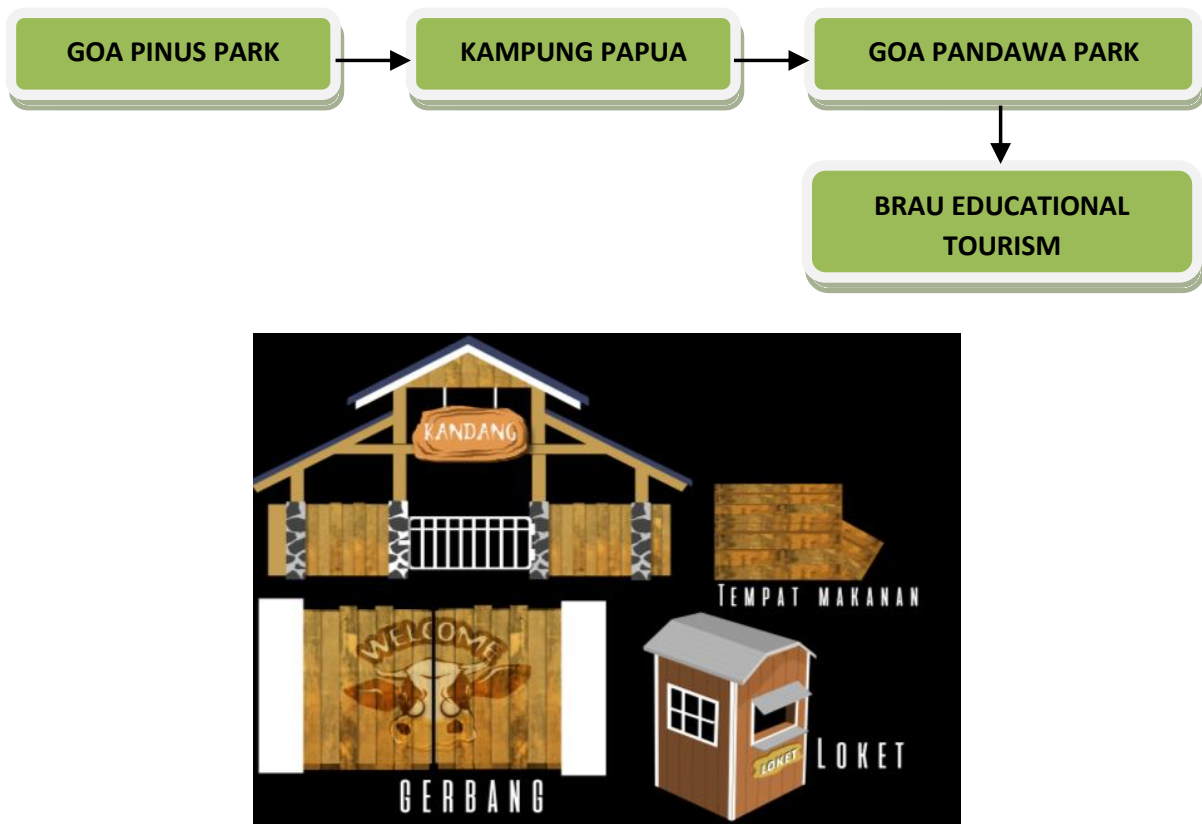

Figure 5. Tourist Flow and Cowhouse Design

Description: Kandang = Cowhouse, tempat makanan $=$ food stall, gerbang $=$ gate, and loket $=$ ticketing .

\section{DISCUSSION}

\section{Research on the Strategy for Tourism} Development

Tourism development strategy was discussed in the Andong Mountain area of Magelang [11], Bumiaji, Batu [1] and Ijen Crater [12]. The research showed that Strength-Opportunity (SO) strategy had the potential to be optimized. It is different to Brau farm edu tourism focusing on Strength-Threat (SO) strategy to be implemented immediately. The SO strategy prioritizes the development agrarian tourism as a new tourist destination, considering tourist variations by organizing folk festivals, collaborating with tourist travel agents, opening climbing equipment rental, visa-free policies as roads or opportunities, forming tour guides and porters [11].

Strategies of the development of communitybased on agro-tourism were also studied in JUHUT Integrated Sheep Village, Banten Province [13]. The results showed Integrated Sheep Village had the potential becoming an agro-tourism destination including optimizing an advocate approach to achieve cooperation with outside parties, establishing agreements on equitable benefits among agro-tourism managers and travel agencies, and improving infrastructure (road, rest area, public toilet, information board map).
Pelaga Village, Petang District, Badung Regency had the potential used as alternative tourism. It was due to the availability of adequate accessibility (roads), supporting facilities, tourist attractions and institutions. There was a support from Pelaga Village community to plan and develop alternative tourism that was in line with the concept used, namely community-based tourism. The concept of tourism applied in Pelaga Village prioritized the involvement of local communities in tourism development in the area [14].

Research on the flower tourism objects in Sidomulyo Village, Bumiaji District, Batu City discussed efforts to develop interest tourism objects in local economic development. The development of flower tourism objects in Sidomulyo Village had a positive impact on local economic development. Besides being able to lift the economy of the community, the development of flower tourism also had other benefits such as the creation of new jobs, namely the existence of horse tours and tubbing. It made the community acquiring new skills or knowledge because many private parties were willing to provide counseling and socialization regarding the development and support of tourism activities. There were several inhibiting factors for tourism development in Sidomulyo Village, namely the lack of socialization to the community about the concept of maps and tour guides that 
had not been formed yet. Sidomulyo community hospitality was the basic capital to attract tourists. However, this needed to be supported by adequate facilities such as good road infrastructure and the establishment of parking areas around tourist areas [15].

Furthermore, there was a research about the development of Jatiluwih Tourism Village in Penebel District, Tabanan Regency. The theory used was destination life cycle analysis, conflict theory, impact theory, participation theory, and perception theory. In developing a tourism village, a social change could occur. In this context, the value of mutual cooperation related to farmer activities, and the rice planting system was increasingly maintained. Traditional arts were increasingly preserved and developed, and their social organizations were increasingly maintained, but some shifts took place. For example, the use of cows or buffaloes to hijack fields has shifted to the use of tractors and the use of organic fertilizers to inorganic fertilizers [16].

The research also found public participation in the planning and supervision stages was manipulative and functional. At the development stage, the community actively was participated. Implementation of the aspects of Pawongan was not good at the planning and supervision stages, but at the development stage, it was going well. Tourist perception on the implementation of the Parahyangan aspect was good. Tourist perceptions of the implementation of the pawongan and palemahan aspects were not good [16].

Research in Brayut Tourism Village, Sleman Regency explained the change of managers greatly had affected the development of Brayut Tourism Village and the most dominant actor in the development of Brayut Tourism Village was the founder of Tourism Village and local government. In addition, the contribution of major Ngayog jazz events also had a positive impact on increasing tourist visits, and it also implicitly promoted Brayut as a tourist village. However, the event seemed more inclined to prioritize aspects of quantity than quality so that the manager felt less professional in developing the village as a tourist visit location [17].

\section{Model of Participatory Development}

From the description in the previous research above, not many has the strategy of developing tourism discussed as a model of participatory development. The participatory development model presses on community partnerships, village government and national private sector in developing tourist destinations. The development of tourist destinations is intended to lead to a village model of ecotourism as sustainable alternative tourism. The concept of ecotourism is a potential development model for maintaining natural resources and supporting the process of improving the local economy [18].

Special tours of agriculture and animal husbandry (farm tourism) originated from ecotourism. This tourism development combines farms and the world of tourism with the attractions of farming or raising experiences. Attractions with the aim of gaining learning experience can be directly programmed through tourism education (edutourism). Therefore, the concept of edufarmtourism is a combination of educational tourism integrated with rural tourism models (farm tourism) and community tourism (community tourism) [19].

One form of participatory planning in tourism development is to implement Community Based Tourism (CBT) as a development approach. Community-based tourism is tourism that is aware of cultural, social and environmental sustainability. This form of tourism is managed by the community, and community helps tourists to increase their awareness and learn about the community and the way of life of the local community $[18,20]$. Furthermore, Suansri [21] reinforces the definition of Community Based Tourism as tourism that takes into account environmental, social and cultural sustainability aspects.

\section{CONCLUSION}

The tourist attraction object in the Brau hamlet that has the potential to be developed is a dairy cattle tourism (edu farm tourism). The analysis showed that the strategy of developing edu tourism farms in Brau Hamlet was in quadrant 1, which means that the strategy is aggressively used using the concentration of vertical integration. Vertical integration is carried out at all stages of the cattle farm supply chain. In the SWOT matrix, the biggest total score of the combination of internal factors and external factors is to strengthen the brand back to nature and always give innovation to tourist rides (S1.5 and $T 1,4)$ of 1.65 . Based on IE matrix analysis, the total value of IFAS and EFAS parameters was in cell 4 , which means the strategy or policy 
taken is a growth strategy by carrying out vertical integration and developing slowly and carefully in tourism management. The scenario for the development of edu tourism farms in Brau Hamlet is progressive.

\section{ACKNOWLEDGEMENT}

Acknowledgments the authors convey to the Ministry of Research, Technology and Higher Education which has helped in the financial sector so that this research could run smoothly. Our thanks are also to the residents of Brau Hamlet, who have been pleased to be informants in supporting this research data and also did not escape thanks to the students of the Faculty of Cultural Studies University of Brawijaya who had helped the author in matters of administration so that the research licensing process could run according to the plan.

\section{REFERENCES}

[1] Attar, M., L. Hakim and B. Yanuwiadi. 2013. Analisis potensi dan arahan strategi kebijakan pengembangan desa ekowisata di Kecamatan Bumiaji-Kota Batu. Journal of Indonesian Tourism and Development Studies 1(2), 68-78.

[2] Kurniawati, E., D. Hamid and L. Hakim. 2018. Peran masyarakat dalam perencanaan dan pengembangan Desa Wisata Tulungrejo Kecamatan Bumiaji Kota Batu. Jurnal Administrasi Bisnis 54(1), 8-14.

[3] Department of National Development Planning. 2008. Dampak pariwisata terhadap perekonomian nasional. Available at: http://kppo.bappenas.go.id/preview/282.

[4] Hermawan, H. 2016. Dampak pengembangan desa wisata Nglanggeran terhadap ekonomi masyarakat lokal. Jurnal Pariwisata 3(1), 105-117.

[5] Fandeli, C. 2000. Pengusahawan ekowisata. Faculty of Forestry, Gadjah Mada University - Natural Resources Conservation, Yogyalarta Special Region. Yogyakarta.

[6] Hunger, J. D. and T. L. Wheleen. 2003. Manajemen strategis (translated). Andi Publisher. Yogyakarta.

[7] Ali, H. 2015. Tourism marketing. Center for Academic Publishing Service. Yogyakarta.

[8] Parmawati, R., R. Imaniyah, L. E. Rokani, M. I. Rajaguni and A. S. Kurnianto. 2018. Ecotourism development strategy of Bukit Jaddih Karst, Madura. Journal of Indonesian
Tourism and Development Studies 6(2), 113-119.

[9] Parmawati, R., A. S. Leksono, B. Yanuwiadi and A. S. Kurnianto. 2018. Exploration of marine tourism in Watulimo, Trenggalek Regency: challenges, potentials, and development strategies. Journal of Indonesian Tourism and Development Studies 5(3), 175-184.

[10] Rangkuti F. 2006. Analisis SWOT teknik membedah kasus bisnis. PT. Gramedia Pustaka Utama. Jakarta.

[11] Saputra, M. R. and Rodhiyah. 2016. Strategi pengembangan wisata di kawasan Gunung Andong Magelang. Jurnal Ilmu Administrasi Bisnis 5(4), 571-586.

[12] Putri, S. D., S. Soemarno and L. Hakim. 2015. Strategic management of naturebased tourism in ljen Crater in the context of sustainable tourism development. Journal of Indonesian Tourism and Development Studies 3(3), 123-129.

[13] Kristiana, Y. and S. Theodora. 2016. Strategi upaya pengembangan pariwisata berkelanjutan agrowisata berbasis masyarakat kampung domba terpadu JUHUT, Provinsi Banten. Jurnal Ilmiah Widya 3(3), 1-7.

[14] Atara, I K. 2011. Strategi pengembangan pariwisata alternatif di Desa Pelaga, Kecamatan Petang, Kabupaten Badung. Master Thesis. Master Program of Tourism Studies, Udayana University.

[15] Yoehansyah, A. 2013. Upaya pengembangan obyek wisata bunga dalam pembangunan ekonomi lokal (studi kasus di Desa Sidomulyo, Kota Batu). Jurnal Administrasi Publik 1(1), 1-9.

[16] Widari, D. A. D. S. 2015. Perkembangan Desa Jatiluwih setelah penetapan Subak sebagai warisan budaya dunia di Kecamatan Penebel Kabupaten Tabanan. Master Thesis. Master Program of Tourism Studies, Udayana University.

[17] Rogi, H. C. 2015. Dinamika pengembangan desa wisata Brayut di Kabupaten Yogyakarta. Bachelor Thesis. Department of Management and Public Policy, Faculty of Social and Political Science, Gadjah Mada University.

[18] Hakim, L. and M. Soemarno. 2017. Biodiversity conservation, community development and geotourism development in bromo-tengger-semeru-arjuno biosphere 
reserve. Geojournal of Tourism and Geosites 20(2), 220-230.

[19] University of California. 2019. Small farms research and extension. Available at: www.sfc.ucdavis.edu.

[20] Hadiwijoyo, S. S. 2012. Perencanaan pariwisata perdesaan berbasis masyarakat: sebuah pendekatan konsep. Graha Ilmu. Yogyakarta.

[21] Suansri, P. 2003. Community Based Tourism Handbook. REST Project. Thailand. 